\title{
Biological Variation in Tests of Hemostasis
}

\author{
Giuseppe Banfi, M.D., and Massimo Del Fabbro, M.D.
}

The publisher regrets errors in the above article as originally printed in Seminars in Thrombosis and Hemostasis, Volume 34, Number 7, 2008, pp 635-641.

The following pages contain the entire text of the corrected article.

${ }^{1}$ IRCCS Galeazzi; ${ }^{2}$ Department of Health Technology, School of Medicine, University of Milan, Milano, Italy.

Address for correspondence and reprint requests: Prof. Giuseppe Banfi, M.D., IRCCS Galeazzi, Via R.Galeazzi 4, 20161, Milano, Italy (e-mail: guiseppe.banfi1@unimi.it).

Laboratory Diagnostics and Therapy in Thrombosis and Hemostasis: From Bedside to Bench to Bedside; Guest Editors, Giuseppe
Lippi, M.D., Emmanuel J. Favaloro, Ph.D., M.A.I.M.S., and Massimo Franchini, M.D.

Semin Thromb Hemost 2009;35:119-126. Copyright (C) 2009 by Thieme Medical Publishers, Inc., 333 Seventh Avenue, New York, NY 10001, USA. Tel: +1(212) 584-4662.

DOI 10.1055/s-0029-1214155. ISSN 0094-6176. 


\title{
Biological Variation in Tests of Hemostasis
}

\author{
Giuseppe Banfi, M.D., ${ }^{1}$ and Massimo Del Fabbro, M.D. ${ }^{1,2}$
}

\section{ABSTRACT}

The two components of biological variability are interindividual variability, which is the variability due to the heterogeneity of physiologic influences among subjects, and intraindividual variability, which is due to the variability in the same individual over time. Analysis of biological variation is crucial for estimating the critical difference, which corresponds with a threshold suggestive of a statistically significant difference between two consecutive results of a laboratory parameter in the same subject and is therefore unlikely attributable to casual (random) oscillation of values. Studies on biological variation of tests of hemostasis are outdated, and the published results should be confirmed by using modern, fully automated methods. Biological variation for coagulation screening tests (prothrombin time and activated partial thromboplastin time) is low and comparable with the values registered for hematologic parameters. However, the index of individuality (ratio between intraindividual and interindividual variability) suggests that the usual preoperative screening for coagulation disorders is influenced by the between-subjects variability. Thrombin time is very constant within and between subjects. Proteins such as fibrinogen, clotting factors, and antithrombin show a low biological variability. In contrast, fibrinolytic parameters, such as plasminogen activator inhibitor 1 and fibrinopeptide $A$, show very high variability, and their interpretation in the clinical setting must take this into consideration.

KEYWORDS: Coagulation tests, biological variation, critical difference, individuality index

The two main components of biological variability (BV) are interindividual variability, which is the variability due to the heterogeneity of physiologic influences among individuals, and intraindividual variability, which is due to the variability in the same individual over time. The biological variability of a laboratory parameter includes the variability of cyclical biological rhythms and the fluctuation beyond a homeostatic value. The amplitude of the fluctuation, which is independent from preanalytical phase, corresponds with the intraindividual variability, reported as a coefficient of variation $\left(\mathrm{CV}_{\mathrm{i}}\right)$. The variability of the homeostatic value within a group of different individuals corresponds with the interindividual variability
$\left(\mathrm{CV}_{\mathrm{g}}\right)$. The total variability $\left(\mathrm{V}_{\mathrm{t}}\right)$ is the sum of analytical $\left(\mathrm{V}_{\mathrm{a}}\right)$ and biological variability $\left(\mathrm{V}_{\mathrm{b}}\right)$. In general, the $\mathrm{V}_{\mathrm{a}}$ is low in automated coagulation testing; thus, $V_{t}$ is highly dependent on $V_{b}$. The traditional analytical goals for laboratory parameters consider $V_{a}=1 / 2 V_{b}$. The $V_{a}$ and $\mathrm{V}_{\mathrm{b}}$ of coagulation parameters (screening tests) are also typically low, fulfilling the analytical goals, but these values are higher for specific and esoteric tests. Fraser has combined the analytical precision $\left(\mathrm{CV}_{\mathrm{a}}\right)$ and the average within-subject biological variation $\left(\mathrm{CV}_{\mathrm{i}}\right)$ from which a critical difference (CD) can be calculated for a predetermined probability. ${ }^{1}$

The CD corresponds with the value indicating that a difference between two consecutive results in the
${ }^{1}$ IRCCS Galeazzi; ${ }^{2}$ Department of Health Technology, School of Medicine, University of Milan, Milano, Italy.

Address for correspondence and reprint requests: Prof. Giuseppe
Banfi, M.D., IRCCS Galeazzi, Via R.Galeazzi 4, 20161, Milano, Italy (e-mail: guiseppe.banfi1@unimi.it). 
same person is statistically significant and it is therefore unlikely attributable to random oscillation of values. In general, difference in results characterized by a probability greater than $95 \%$ of representing a true change in a person is described as $\mathrm{CD}^{95}=2.77 \times\left(\mathrm{CV}_{\mathrm{a}}^{2}+\mathrm{CV}_{\mathrm{i}}^{2}\right)^{1 / 2}$. The factor 2.77 is equal to $\sqrt{ } 2$ times the $\mathrm{z}$ score for the difference. $\mathrm{CD}$, in other words, identifies whether an external factor (acute disease, therapy, physical exercise, diet, etc.) can really impact on results of a given parameter and if the modification is independent from instrumental or biological variabilities.

The ratio between intraindividual and interindividual variability is referred to as individuality index $\left(\mathrm{II}=\mathrm{CV}_{\mathrm{i}} / \mathrm{CV}_{\mathrm{g}}\right)$. The II provides information about the biological individuality of a given laboratory $\mathrm{pa}^{-}$ rameter and, primarily, about the usefulness of the reference ranges calculated on a population of apparently healthy individuals. The reference interval is traditionally appropriate when II is $>1.4$; when the II is $<1.0$, the reference interval is inappropriate, and when the II is $<0.6$, the reference interval should not be used. ${ }^{2}$

There are only a few studies on the biological variability of coagulation parameters, and they are generally outdated. Thus, results from these articles are biased by obsolete methods and technologies, as a continuous development and diffusion of automated devices has occurred over recent years, leading to a substantial improvement of precision and throughput. In a data bank of biological variability of laboratory parameters published 11 years ago and based on 107 publications from 1951 until 1996, only one study included prothrombin time (PT) and activated partial thromboplastin time (APTT). ${ }^{3}$ Although the current review has the limit of heterogeneity of both sources and methods used for measuring coagulation parameters, the data reported, extrapolated from different epidemiologic or clinical studies, are however mostly concordant, and they could be of practical value for routine and research laboratories.

\section{SCREENING TESTS}

In a population of 39 subjects (19 women, 20 men; age range, 20 to 49) followed at monthly intervals for a period of 9 months, the intraindividual biological variation of PT, calculated as a mean CV, was $2.3 \%$, and the interindividual biological variation was $6.8 \%$. The corresponding values for the APTT were 2.1\% (intraindividual) and $8.9 \%$ (interindividual), respectively. ${ }^{4}$ The authors ${ }^{4}$ also calculated the median intraindividual CV for the two parameters, and the values were lower than mean data: $1.7 \%$ for PT and actually $0.0 \%$ for APTT. These values differ broadly from those originally quoted by Costongs et $\mathrm{al}^{5}{ }^{5}$ (5.8\% for PT and $6.8 \%$ for APTT), which are however not considered in the current review.
In a companion paper, Costongs et $\mathrm{al}^{6}$ actually reported values very similar to those described by Dot et $\mathrm{al}^{4}: 0.9 \%$ (median intra-individual $\mathrm{CVs}$ ) for PT, and 3.4\% for APTT in long-term (six months) evaluation. In a study performed on 17 Japanese subjects ${ }^{7}$ (8 males, 9 females; age range: $20-60$ years) the $\mathrm{CV}_{\mathrm{i}}$ values for $\mathrm{PT}$ and APTT were lower than those reported by Costongs et $\mathrm{al}^{6}$ and more consistent with those reported by Dot et $\mathrm{al}^{4}$ : the values were $2.4 \%$ for PT and $3.3 \%$ for APTT. The authors ${ }^{7}$ highlighted that analytical techniques were changed and improved since 1985 when Costongs et $\mathrm{al}^{6}$ published their values, which were also derived from a population including smokers and women taking oral contraceptives, major differences that could explain the discrepancies between the two studies. Wada et $\mathrm{al}^{7}$ described $\mathrm{CV}_{\mathrm{g}}$ of $4.0 \%$ for PT and $7.1 \%$ for APTT. It is interesting to note that the CVs calculated for APTT reported as percentage or for international normalized ratio (INR) were higher than the $\mathrm{CVs}$ calculated for the respective clotting times (seconds): $\mathrm{CV}_{\mathrm{i}}$ of $5.6 \%$ and $\mathrm{CV}_{\mathrm{g}}$ of $9.4 \%$ for percentage values, $\mathrm{CV}_{\mathrm{i}}$ of $3.0 \%$ and $\mathrm{CV}_{\mathrm{g}}$ of $4.0 \%$ for INR.

A value of $C V_{i}$ of $4 \%$ for prothrombin time is reported in a database. ${ }^{8}$ This value was used by Kouri et $\mathrm{al}^{9}$ for a comparison with the combined preanalytical and analytical uncertainty of measurement, which they observed to be higher (5.6\%) than the $\mathrm{CV}_{\mathrm{i}}$. In 32 patients taking anticoagulants, the $\mathrm{CV}_{\mathrm{i}}$ of the PT, evaluated on samples taken every 5 weeks during a period of 6 months, was $10.1 \%$, thus higher than that reported in healthy subjects. ${ }^{10}$ The BV data of PT and APTT could be compared with those reported for platelet count, a parameter used as first-line test for diagnosing hemostasis disorders. ${ }^{11} \mathrm{~A} \mathrm{CV}_{\mathrm{i}}$ of $9 \%$ and a $\mathrm{CV}_{\mathrm{g}}$ of $23 \%$ were described for platelet count. ${ }^{3}$

Dot et $\mathrm{al}^{4}$ also calculated the CD: $19 \%$ for PT and $16 \%$ for APTT. The II was 0.96 for PT and 0.68 for APTT, concluding that reference values for these tests derived from general populations are more appropriate for longitudinal comparison than for diagnosing diseases. This topic is particularly interesting and of practical value, because the usual preoperative screening for coagulation disorders based on PT and APTT is largely influenced by the interindividual variability.

\section{FIBRINOGEN}

Costongs et $\mathrm{al}^{6}$ described a median intraindividual $\mathrm{CV}$ of $3.5 \%$ during a short-term evaluation, based on 1-day calculation in 60 individuals. The $\mathrm{CD}$ was $13.2 \%$. When the calculation of variability was performed by the same authors on a group of 274 individuals during a long-term period (6 months), the median $\mathrm{CV}_{\mathrm{i}}$ was $10 \%$ and the CD was $29.6 \%$. The data reported by Sakkinen et $\mathrm{al}^{12}$ on 26 subjects observed during a period of 6 months are similar: $18.6 \%$ and $20.2 \%$ for intraindividual and 
Table 1 Biological Variation of Various Hemostasis Parameters: Part 1

\begin{tabular}{|c|c|c|c|c|c|}
\hline Parameter & $\begin{array}{l}\text { Time Span } \\
\text { Range }\end{array}$ & $\begin{array}{l}\text { Number of Examined } \\
\text { Subjects }\end{array}$ & & & Reference \\
\hline & $1 d$ & $60(23 \mathrm{M}, 37 \mathrm{~F})$ & Median $\mathrm{CV}_{\mathrm{i}}$ & Median $\mathrm{CV}_{\mathrm{g}}$ & $6^{*}$ \\
\hline Thrombin time & & & 0.0 & & \\
\hline Antithrombin III & & & 5.2 & & \\
\hline$\alpha_{2}$-antiplasmin & & & 6.6 & & \\
\hline Plasminogen & & & 3.8 & & \\
\hline & $6 \mathrm{mo}$ & $274(148 \mathrm{M}, 126 \mathrm{~F})$ & Median $\mathrm{CV}_{\mathrm{i}}$ & Median $\mathrm{CV}_{\mathrm{g}}$ & $5^{*}$ \\
\hline Thrombin time & & & 0.0 & & \\
\hline Antithrombin III & & & 3.1 & & \\
\hline$\alpha_{2}$-antiplasmin & & & 6.6 & & \\
\hline Plasminogen & & & 3.8 & & \\
\hline & $3-6 w k$ & 39 (16 M, $23 \mathrm{~F})$ & $\mathrm{CV}_{\mathrm{i}}^{\dagger}$ & & 22 \\
\hline Fibrinopeptide $A^{\ddagger}$ & & & 80.3 & & \\
\hline D-dimer ${ }^{\ddagger}$ & & & 17.4 & & \\
\hline$\beta$-thromboglobulin $\ddagger$ & & & 9.5 & & \\
\hline Platelet factor $4^{\ddagger}$ & & & 12.5 & & \\
\hline Tissue plasminogen activator ${ }^{\ddagger}$ & & & 11.1 & & \\
\hline Plasminogen activator inhibitor $1^{\ddagger}$ & & & 53 & & \\
\hline Protein $S^{\S}$ & & & 2.9 & & \\
\hline Tissue plasminogen activator ${ }^{\ddagger}$ & $6 \mathrm{mo}$ & $20(10 \mathrm{M}, 10 \mathrm{~F})$ & Mean $\mathrm{CV}_{\mathrm{i}}$ & $\begin{array}{l}\text { Mean } \mathrm{CV}_{\mathrm{g}} \\
97\end{array}$ & 13 \\
\hline & $3 \mathrm{mo}$ & $34 \mathrm{~F}$ (postmenopausal) & Mean $\mathrm{CV}_{\mathrm{i}}$ & Mean $\mathrm{CV}_{\mathrm{g}}$ & 21 \\
\hline Tissue plasminogen activator ${ }^{\ddagger}$ & & & 11 & & \\
\hline Plasminogen activator inhibitor $1^{\ddagger}$ & & & 55 & & \\
\hline Plasmin- $\alpha_{2}$-antiplasmin complex ${ }^{\ddagger}$ & & & 17 & & \\
\hline Thrombin-antithrombin complex ${ }^{\ddagger}$ & & & 11 & & \\
\hline & $24 w k$ & $26(10 \mathrm{M}, 16 \mathrm{~F})$ & Mean $\mathrm{CV}_{\mathrm{i}}$ & Mean $\mathrm{CV}_{\mathrm{g}}$ & II (Ref. ${ }^{12}$ ) \\
\hline Fibrinopeptide $A^{\ddagger}$ & & & 82.7 & 45.8 & 1.77 \\
\hline D-dimer $r^{\ddagger}$ & & & 56.4 & 89.5 & 0.63 \\
\hline Tissue plasminogen activator ${ }^{\ddagger}$ & & & 15.0 & 45.6 & 0.33 \\
\hline Plasminogen activator inhibitor $1^{\ddagger}$ & & & 47.2 & 70.9 & 0.67 \\
\hline $\begin{array}{l}\text { Tissue plasminogen activator- } \\
\text { plasminogen activator inhibitor } \\
1 \text { complex }\end{array}$ & & & 22.4 & 59.3 & 0.38 \\
\hline Plasmin- $\alpha_{2}$-antiplasmin complex & & & 19.9 & 29.3 & 0.68 \\
\hline Prothrombin fragment F1-2 & & & 24.2 & 28.3 & 0.85 \\
\hline Thrombin-antithrombin complex ${ }^{\ddagger}$ & & & 25.0 & 60.5 & 0.41 \\
\hline & $12 \mathrm{mo}$ & $17(8 \mathrm{M}, 9 \mathrm{~F})$ & Mean $\mathrm{CV}_{\mathrm{i}}$ & Mean $\mathrm{CV}_{\mathrm{g}}$ & 7 \\
\hline$\alpha_{2}$-antiplasmin inhibitor ${ }^{\S}$ & & & 4.8 & 7.1 & \\
\hline Plasminogen ${ }^{\S}$ & & & 4.2 & 10.5 & \\
\hline Thrombin-antithrombin complex & & & 26.0 & 20.0 & \\
\hline Plasmin- $\alpha_{2}$-antiplasmin complex & & & 18.0 & 26.0 & \\
\hline Thrombomodulin ${ }^{\ddagger}$ & & & 11.4 & 16.5 & \\
\hline $\begin{array}{l}\text { Tissue plasminogen activator- } \\
\text { plasminogen activator } \\
\text { inhibitor } 1 \text { complex }{ }^{\ddagger}\end{array}$ & & & 15.9 & 31.2 & \\
\hline Protein $S^{\S}$ & & & 7.6 & 22.3 & \\
\hline Protein $C^{\S}$ & & & 7.9 & 17.5 & \\
\hline
\end{tabular}

*The measured values and the kind of measures are not specified.

${ }^{\dagger}$ It is not specified if the CV is a median or a mean.

${ }^{\ddagger}$ Quantity measured as mass concentration.

${ }^{\S}$ Quantity measured as percentage.

$\mathrm{d}$, day; wk, week; mo, month; M, male; F, female; CV, coefficient of variation (\%); II, index of individuality. 
interindividual variability, respectively. In a further study on 59 healthy individuals, the $\mathrm{CV}_{\mathrm{g}}$ was $15 \%,{ }^{13}$ whereas in a longitudinal study performed over 1 year on 26 subjects (13 men, 13 women; age range, 25 to 52 years), the $C V_{\mathrm{i}}$ was $13.5 \%$ and the $C V_{\mathrm{g}}$ was $16.2 \% .{ }^{14} \mathrm{In}$ a study including 17 subjects ( 8 males, 9 females; age range, 20 to 60 years), the $C V_{\mathrm{i}}$ was $8.7 \%$ and the $\mathrm{CV}_{\mathrm{g}}$ was $14.8 \%{ }^{7}$ In synthesis, all the studies are concordant on the values of the biological variability of fibrinogen. The variation of fibrinogen during a 1-year longitudinal study performed on 206 Finnish subjects aged 50 to 60 years was not linked to genetic polymorphisms, namely TaqI and $B c l$ mapped to the $3^{\prime}$ end of the $\alpha$ - and the $\beta$-fibrinogen genes, and HindIII, based on the presence of either $\mathrm{C}$ or $\mathrm{T}$ base at position -148 upstream from the start of the transcription site of the $\beta$-fibrinogen gene. ${ }^{15}$ Genetic influence explains $39 \%$ of variation; however, no quantitative differences of genetic influence on hemostatic levels were observed between males and females, as reported in a study involving 93 monozygotic twin pairs (44 males and 49 females) and 116 dizygotic twin pairs (36 males, 40 females, 40 opposite sex). ${ }^{16}$

The values reported for fibrinogen, which is typically increased during acute phase and atherosclerosis, are similar to those found for other parameters (cholesterol, triglycerides, blood pressure) traditionally used for assessing cardiovascular risk. ${ }^{17,18}$ Fibrinogen concentrations are correlated with cardiovascular risk factors, but modifiable lifestyle characteristics (smoking, alcohol consumption, physical activity, obesity) only explain a few percent of the total variation, as reported in a meta-analysis of 31 prospective studies, including 154,211 adults. ${ }^{19}$ Fibrinogen $\mathrm{CV}_{\mathrm{i}}$ was also not increased in patients with underlying disease compared with healthy controls. ${ }^{13}$ It is noteworthy that the association with body mass index was twice as strong in women as in men. ${ }^{19}$

\section{COAGULATION FACTORS}

The median intraindividual variation in a short-term evaluation (within 1 day) was nil (0.0\%) for factor $\mathrm{V}$ and $4.8 \%$ for factor $\mathrm{X}$; the corresponding $\mathrm{CDs}$ were 9.9\% and $14.9 \%{ }^{6} \mathrm{~A}$ higher value for factor $\mathrm{V}\left(\mathrm{CV}_{\mathrm{i}}\right.$ $3.6 \%)$ is, however, reported in a database. ${ }^{8}$ Long-term evaluation, over a 6-month period, yielded an intraindividual variability of $3.6 \%$ for factor $\mathrm{V}$ and $5.9 \%$ for factor $\mathrm{X}$, resulting in a CD of $14.2 \%$ and $17.8 \%$, respectively. ${ }^{5}$ The intraindividual variability of factor VIII, as evaluated during a pharmacokinetic study, was $8.6 \%{ }^{20}$ The within-subject mean $\mathrm{CV} \%$ for factor VII in 34 postmenopausal women followed during a period of 3 months was $8.5 \%$ : the proportion on the total variance of the intraindividual variability was $5 \%$. The corresponding values for factor VIII were $16 \%$ and $19 \% .^{21}$

\section{ADDITIONAL PARAMETERS}

The biological variations of various hemostasis parameters are summarized in Tables 1 and 2. Low values of biological variability were described for antithrombin, plasminogen, and $\alpha_{2}$-antiplasmin. Identical $\mathrm{CV}_{\mathrm{i}}$ has been reported for tissue plasminogen activator (tPA) in two different studies. A high variability characterizes thrombin-antithrombin complex, plasmin- $\alpha_{2}$ antiplasmin complex, prothrombin fragment $1+2$ (F1-2), whereas that of plasminogen activator inhibitor 1 (PAI-1) and fibrinopeptide A is even higher. These data suggest that an accurate and appropriate interpretation of laboratory results should be advisable when these data are used for establishing either a diagnosis or the prognosis.

\section{EVALUATION OF THE PROPORTION OF INTRAINDIVIDUAL AND INTERINDIVIDUAL VARIABILITY}

In some studies, the intraindividual and interindividual biological variability was reported as a proportion of the total variability; in others ${ }^{18,23,24}$ the intraindividual variability is included in the analytical variability. In the study of Thompson et al, ${ }^{24}$ the sum of $\mathrm{CV}_{\mathrm{i}}$ and $\mathrm{CV}_{\mathrm{g}}$ is not equal to 100 because the authors also included a between-batch variation, due to analytical phase, representing the difference between total variation and the sum of between-subject and within-subject variations. Only for fibrinogen was the between-batch variation equal to $0 \%$. Discrepant results were observed only for tissue plasminogen activator: two studies are concordant, whereas a third one showed very high CVi. A very high $\mathrm{CVi}$ for fibrinogen was reported in one paper only (Table 2).

\section{GENDER AND AGE}

The median intraindividual variability of plasminogen showed a significant difference in a 1-day short-term evaluation between males $(n=23 ; \mathrm{CV}=3 \%)$ and females $(n=37 ; \mathrm{CV}=4.3 \%)$. Females who used oral contraceptives had higher values (11.5\%) than did nonusers (7.3\%). ${ }^{6}$ This difference could not be confirmed in a population of 473 subjects (208 males and 265 females) after a 3-year follow-up. The proportion of intraindividual variance of the total variance for plasminogen was $51 \%$ in males and $55 \%$ in women. ${ }^{18}$ Although a large study on a general population reported higher levels of von Willebrand factor (VWF) in women when compared with men, ${ }^{25}$ this difference could not be confirmed in a study on a wide series of twins. ${ }^{16}$ It should be outlined, however, that the influence of genetic factors on VWF concentrations is high $(72 \%)^{16}$ and VWF levels of blood group $\mathrm{O}$ individuals are $25 \%$ lower than those in non-O individuals. ${ }^{26} \mathrm{~A}$ gender difference has been reported for 
Table 2 Biological Variation of Various Hemostasis Parameters: Part 2

\begin{tabular}{|c|c|c|c|c|}
\hline Parameters & $\mathrm{CV}_{\mathrm{i}}(\%)$ & $\mathrm{CV}_{\mathrm{g}}(\%)$ & $\begin{array}{l}\text { Time Span } \\
\text { Range }\end{array}$ & $\begin{array}{l}\text { Number of Subjects Studied } \\
\text { and Reference }\end{array}$ \\
\hline Tissue plasminogen activator* & 49 & 51 & $1 y$ & $16 \mathrm{M}$, age $20-30 \mathrm{y}, 79$ observations ${ }^{23}$ \\
\hline Tissue plasminogen activator* & 3 & 97 & $6 \mathrm{mo}$ & 20 (10 M, 10 F), 9 observations ${ }^{13}$ \\
\hline Tissue plasminogen activator* & 4 & 96 & $3 \mathrm{mo}$ & $34 \mathrm{~F}$ (postmenopausal) ${ }^{21}$ \\
\hline Factor II & 32 & 72 & $3 y$ & $14(6 \mathrm{M}, 8 \mathrm{~F}), 20$ observations $^{24}$ \\
\hline Factor $I^{\dagger}$ & 11 & 89 & $3 \mathrm{mo}$ & $34 \mathrm{~F}$ (postmenopausal) ${ }^{21}$ \\
\hline Factor VII & 42 & 58 & $1 y$ & $16 \mathrm{M}$, age $20-30 \mathrm{y}, 79$ observations ${ }^{23}$ \\
\hline Factor VII:c & 37 & 63 & $3 y$ & $208 \mathrm{M}$, age $45-64$ y, 2 observations ${ }^{18}$ \\
\hline Factor VII: $\mathrm{C}^{\dagger}$ & 38 & 62 & $3 y$ & $265 \mathrm{~F}$, age $45-64$ y, 2 observations ${ }^{18}$ \\
\hline Factor VII ${ }^{\dagger}$ & 5 & 95 & $3 \mathrm{mo}$ & $34 \mathrm{~F}$ (postmenopausal) ${ }^{21}$ \\
\hline Factor VII & 57 & 43 & $3 y$ & $208 \mathrm{M}$, age $45-64$ y, 2 observations ${ }^{18}$ \\
\hline Factor VII:Ag & 58 & 42 & $3 y$ & $265 F$, age $45-64$ y, 2 observations ${ }^{18}$ \\
\hline Factor VIII ${ }^{\dagger}$ & 34 & 57 & $3 y$ & $14(6 \mathrm{M}, 8 \mathrm{~F}), 20$ observations $^{24}$ \\
\hline Factor VIII ${ }^{\dagger}$ & 19 & 81 & $3 \mathrm{mo}$ & $34 \mathrm{~F}$ (postmenopausal) $)^{21}$ \\
\hline Factor $\mathrm{X}^{\dagger}$ & 35 & 47 & $3 y$ & $14(6 \mathrm{M}, 8 \mathrm{~F}), 20$ observations $^{24}$ \\
\hline $\begin{array}{l}\text { Von Willebrand } \\
\text { factor-related antigen }{ }^{\dagger}\end{array}$ & 28 & 71 & $3 y$ & 14 (6 M, 8 F), 20 observations $^{24}$ \\
\hline Antithrombin III ${ }^{\dagger}$ & 48 & 13 & $3 y$ & $14(6 \mathrm{M}, 8 \mathrm{~F}), 20$ observations $^{24}$ \\
\hline Fibrinogen* & 67 & 33 & $1 \mathrm{y}$ & $16 \mathrm{M}$, age $20-30 \mathrm{y}, 79$ observations $^{23}$ \\
\hline Fibrinogen* & 33 & 67 & $3 y$ & $208 \mathrm{M}$, age $45-64$ y, 2 observations ${ }^{18}$ \\
\hline Fibrinogen* & 39 & 61 & $3 y$ & $265 \mathrm{~W}$, age $45-64$ y, 2 observations ${ }^{18}$ \\
\hline Fibrinogen* & 13 & 87 & $6 \mathrm{mo}$ & $20(10 \mathrm{M}, 10 \mathrm{~F}, 9 \text { observations })^{13}$ \\
\hline Fibrinogen* & 28 & 72 & $3 y$ & $14(6 \mathrm{M}, 8 \mathrm{~F}), 20$ observations $^{24}$ \\
\hline Plasminogen ${ }^{\dagger}$ & 51 & 49 & $3 y$ & $208 \mathrm{M}$, age $45-64$ y, 2 observations ${ }^{18}$ \\
\hline Plasminogen ${ }^{\dagger}$ & 55 & 45 & $3 y$ & $265 \mathrm{~F}$, age $45-64$ y, 2 observations, ${ }^{18}$ \\
\hline Plasminogen activator inhibitor $1^{*}$ & 9 & 91 & $3 \mathrm{mo}$ & $34 \mathrm{~F}$ (postmenopausal) ${ }^{21}$ \\
\hline Plasmin- $\alpha_{2}$-antiplasmin complex* & 17 & 83 & $3 \mathrm{mo}$ & 34 women (postmenopausal) ${ }^{21}$ \\
\hline Thrombin-antithrombin complex* & 20 & 80 & $3 \mathrm{mo}$ & 34 women (postmenopausal) ${ }^{21}$ \\
\hline
\end{tabular}

*Quantity measured as mass concentration.

$\dagger$ Quantity measured as percentage.

mo, month; y, year.

activated protein $\mathrm{C}(\mathrm{APC})$ resistance on a population of 104 women and 119 men $(p<0.01) .{ }^{27}$ Gender variability on thrombophilia-associated markers has been occasionally described. Thus, a small but statistically significant effect on protein $\mathrm{S}$ and antithrombin was described in one study, with females displaying slightly lower levels of the former and slightly higher levels of the latter. ${ }^{28}$ Antithrombin and protein $C$ levels have been reported as higher in males than in females, ${ }^{29-31}$ whereas in other studies higher values were reported in females. ${ }^{25,32}$ Age has also a small but significant effect on thrombophilia-associated markers. Protein $\mathrm{C}$ and protein $\mathrm{S}$ both increase in the elderly, whereas antithrombin decreases in both genders, ${ }^{28,31}$ although an increase of antithrombin has also been reported in women. ${ }^{29}$ Plasma PAI-1 activity is the main determinant of whole blood fibrinolytic activity in females, whereas tPA and PAI- 1 activities equally contribute in males. ${ }^{33}$ The association of the tPA activity with gender and age was confirmed by Stegnar, ${ }^{34}$ although the correlation was not confirmed in a more recent paper from the same group. ${ }^{35}$ A positive correla- tion between increased concentration and/or activity and increasing age has been described for fibrinogen, ${ }^{19}$ VWF, ${ }^{16}{ }^{1 P A},{ }^{16,34,35}$ PAI- $1,{ }^{36}$ and D-dimer. ${ }^{34}$ For thrombin-antithrombin complex, a negative correlation was reported. ${ }^{34}$

\section{CORRELATION WITH BODY MASS INDEX}

A strong association between fibrinogen levels and body mass index (BMI) has been reported in women, but not in men. ${ }^{19,37}$ Factors VII, VIII, XII, and F1-2 correlate with BMI. ${ }^{37}$ There are conflicting data on VWF: Bowles et $\mathrm{al}^{37}$ did not observe a significant correlation, but this finding was disputed by Conlan et al. ${ }^{25} \mathrm{~A}$ similar scenario was depicted for D-dimer: Bowles et $\mathrm{al}^{37}$ did not show a significant correlation between D-dimer and BMI, whereas Cushman et al did. ${ }^{38}$ Increasing BMI was also associated with an impaired fibrinolytic activity: tPA activity fell significantly and PAI-1 rose as BMI increased. ${ }^{34,37} \mathrm{~A}$ rise of antithrombin activity and protein $\mathrm{C}$ was related to high 
BMI, reflecting a compensatory response to activated coagulation and impaired fibrinolysis. ${ }^{37}$

\section{CIRCADIAN RHYTHMS}

Haus et $\mathrm{al}^{39}$ observed lower PT values at night, whereas a peak was recorded in the afternoon. APTT, on the contrary, showed a peak in the evening or at night, although the magnitude of variation was small $(<10 \%) .{ }^{39}$ A nocturnal peak was reported for thrombin time, ${ }^{39}$ whereas a morning peak and nocturnal lower levels have been described for fibrinogen. ${ }^{39,41}$ A morning peak and a trough in the evening or at night have been described for factor VIII activity. ${ }^{39,40}$ A lack of circadian rhythm was demonstrated for antithrombin activity, ${ }^{39,40}$ factor $\mathrm{V}$, and plasminogen. ${ }^{39} \mathrm{~A}$ marked circadian rhythm was instead observed for tPA, which is characterized by an early morning fall and a peak in the afternoon, with a peak-trough difference of nearly $150 \% .{ }^{41}$ The circadian variation of PAI- 1 showed a time course opposite to that of tPA, showing an early morning peak and a trough in the afternoon, with a variation of nearly $200 \% .{ }^{41}$ No circadian rhythm was observed for plasminogen. ${ }^{41} \mathrm{~A}$ circannual rhythm was reported for antithrombin, which is increased in healthy volunteers during the summer, whereas fibrinolytic activity is increased at low temperature. ${ }^{42}$ Fibrinogen concentrations exhibited a significant high amplitude yearly variation (peak-trough is close to $28 \%$ ). Peak values were observed in the period February-June and in December, whereas lower values occurred in January and the period August-September. ${ }^{14}$ In diabetic patients, the peak of vWF was found in the morning. ${ }^{39}$

\section{CONCLUSION}

Biological variability for coagulation screening tests (PT and APTT) is generally low and comparable with the values reported for traditional hematologic parameters. However, the index of individuality (ratio between intraindividual and interindividual variability) suggests that the usual preoperative screening for coagulation disorders might be substantially influenced by the between-subjects variability. Thrombin time is very constant within and between subjects. Proteins, such as fibrinogen, clotting factors, and antithrombin, display a low biological variability. In contrast, PAI-1 and fibrinopeptide A show very high variability, and their interpretation in the clinical setting requires caution. The data reported in this article were collected from various sources, often outdated, and are heterogeneous for the high variability of methods, number of subjects studied, and interpretation of results. All these variables should be taken into consideration when using these data for clinical purposes. Accordingly, multicenter studies, enrolling a heterogeneous population and using modern analytical methods, are needed to definitively assess the impact of biological variability on hemostasis tests.

\section{REFERENCES}

1. Fraser CG. Inherent biological variation and reference values. Clin Chem Lab Med 2004;42:758-764

2. Fraser CG, Wilkinson SP, Neville RG, et al. Biologic variation of common hematologic quantities in the elderly. Am J Clin Pathol 1989;92:465-470

3. Sebastian-Gambaro MA, Lirón-Hernández J, FuentesArderiu X. Intra- and inter-individual biological variability data bank. Eur J Clin Chem Clin Biochem 1997;35:845852

4. Dot D, Mirò J, Fuentes-Arderiu X. Within-subject biological variation of prothrombin time and activated partial thromboplastin time. Ann Clin Biochem 1992;29:422-425

5. Costongs GMPJ, Janson PCW, Bas BM, Hermans J, Brombacher PJ, van Wersch JWJ. Short-term and long-term intraindividual variations and critical differences of haematological laboratory parameters. J Clin Chem Clin Biochem 1985;23:69-76

6. Costongs GMPJ, Bas BM, Janson PCW, et al. Short-term and long-term intraindividual variations and critical differences of coagulation parameters. J Clin Chem Clin Biochem 1985;23:405-410

7. Wada Y, Kutihara M, Toyofuku M, et al. Analytical goals for coagulation tests based on biological variation. Clin Chem Lab Med 2004;42:79-83

8. Ricos C, Alvarez V, Cava F, et al. Current databases on biological variation: pros, cons and progress. Scand J Clin Lab Invest 1999;59:491-500

9. Kouri T, Siloaho M, Pohjavaara S, et al. Pre-analytical factors and measurement uncertainty. Scand J Clin Lab Invest 2005;65:463-475

10. Lassen JF, Branslund I, Antonsen S. International normalized ratio for prothrombin times in patients taking oral anticoagulants: critical difference and probability of significant change in consecutive measurements. Clin Chem 1995;41: 444-447

11. Lippi G, Franchini M, Guidi GC. Diagnostic approach to inherited bleeding disorders. Clin Chem Lab Med 2007;45: 2-12

12. Sakkinen PA, Macy EM, Callas PW, et al. Analytical and biologic variability in measures of hemostasis, fibrinolysis, and inflammation: assessment and implications for epidemiology. Am J Epidemiol 1999;149:261-267

13. de Maat MP, de Bart AC, Hennis BC, et al. Interindividual and intraindividual variability in plasma fibrinogen, TPA antigen, PAI activity, and CRP in healthy, young volunteers and patients with angina pectoris. Arterioscler Thromb Vasc Biol 1996;16:1156-1162

14. Maes M, Scharpé S, Cooreman W, et al. Components of biological, including seasonal, variation in haematological measurements and plasma fibrinogen concentrations in normal humans. Experientia 1995;51:141-149

15. Väisänen S, Rauramaa R, Penttilä I, et al. Variation in plasma fibrinogen over one year: relationships with genetic polymorphisms and non-genetic factors. Thromb Haemost 1997; 77:884-889 
16. De Lange M, de Geus EJC, Kluft C, et al. Genetic influences on fibrinogen, tissue plasminogen activator-antigen and von Willebrand factor in males and females. Thromb Haemost 2006;95:414-419

17. Chambless LE, McMahon RP, Brown SA, Patsch W, Heiss G, Shen Y. Short-term intraindividuality variability in lipoprotein measurements: the atherosclerosis risk in communities study. Am J Epidemiol 1992;136:1069-1081

18. Salomaa V, Rasi V, Stengård J, et al. Intra- and interindividual variability of hemostatic factors and traditional cardiovascular risk factors in a three-year follow-up. Thromb Haemost 1998;79:969-974

19. The Fibrinogen Studies Collaboration. Associations of plasma fibrinogen levels with established cardiovascular disease risk factors, inflammatory markers, and other characteristics: individual participant meta-analysis of 154,211 adults in 31 prospective studies. Am J Epidemiol 2007;166:867-879

20. Bolon-Larger M, Chamouard V, Bressolle F, Boulieu R. A limited sampling strategy for estimating individual pharmacokinetic parameters of coagulation of coagulation factor VIII in patients with hemophilia A. Ther Drug Monit 2007;29: 20-26

21. Horne MK, McCloskey DJ, Cullinane AM, et al. Parameters of coagulant and fibrinolytic capacity and activity in postmenopausal women: within-subject variability. Thromb Res 2002;107:229-233

22. Nguyen ND, Ghaddar H, Stinson V, Chambless LE, Wu KK. ARIC hemostasis study - IV. Intraindividual variability and reliability of hemostatic factors. Thromb Haemost 1995; 73:256-260

23. Marckmann P, Sandström B, Jespersen J. The variability of and association between measures of blood coagulation, fibrinolysis and blood lipids. Atherosclerosis 1992;96:235-244

24. Thompson SG, Martin JC, Meade TW. Sources of variability in coagulation factor assays. Thromb Haemost 1987;58:10731077

25. Conlan MG, Folsom AR, Finch A, et al. Association of factor VIII and von Willebrand factor with age, sex and risk factors for atherosclerosis. The Atherosclerosis Risk in Communities (ARIC) study. Thromb Haemost 1993;70: 380-385

26. Lippi G, Franchini M, Brocco G, Manzato F. Influence of the ABO blood type on the platelet function analyzer PF100. Thromb Haemost 2001;85:369-370

27. Freyburger G, Bilhou-Nabera C, Dief S, et al. Technical and biological conditions influencing the functional APC resistance test. Thromb Haemost 1996;75:460-465

28. Favaloro EJ, Soltani S, McDonald J, Grezchnik E, Easton L. Laboratory identification of familial thrombophilia: do the pitfalls exceed the benefits? A reassessment of ABO blood group, gender, age, and other laboratory parameters on the potential influence on a diagnosis of protein $\mathrm{C}$, protein $\mathrm{S}$, and antithrombin deficiency and the potential high risk of a false positive diagnosis. Lab Hematol 2005;11:174-184

29. Dolan G, Neal K, Cooper P, Brown P, Preston FE. Protein C, antithrombin III and plasminogen: effect of age, sex and blood group. Br J Haematol 1994;86:798-803

30. Rodeghiero F, Tosetto A. The VITA project: populationbased distributions of protein $\mathrm{C}$, antithrombin III, heparincofactor II and plasminogen - relationship with physiological variables and establishment of reference ranger. Thromb Haemost 1996;76:226-233

31. Tait RC, Walker ID, Islam SI, et al. Protein C activity in healthy volunteers - influence of age, sex, smoking and oral contraceptives. Thromb Haemost 1993;70:281-285

32. Sakkinen PA, Cushman M, Patsy BM, et al. Correlates of antithrombin, protein $\mathrm{C}$, protein $\mathrm{S}$, and TFPI in a healthy elderly cohort. Thromb Haemost 1998;80:134-139

33. MacCallum PK, Cooper JA, Howarth DJ, Meade TW, Miller GJ. Sex differences in the determinants of fibrinolytic activity. Thromb Haemost 1998;79:587-590

34. Stegnar M, Pentek M. Fibrinolytic response to venous occlusion in healthy subjects: relationship to age, gender, body weight, blood lipids and insulin. Thromb Res 1993;69: 81-92

35. Stegnar M, Cuderman TV, Boič M. Evaluation of preanalytical, demographic, behavioural and metabolic variables on fibrinolysis and haemostasis activation markers utilised to assess hypercoagulability. Clin Chem Lab Med 2007;45:40-46

36. Hashimoto Y, Kobayashi A, Yamazaki N, Sugawara Y, Takada Y, Takada A. relationship between age and plasma tPA, PA-inhibitor and PA activity. Thromb Res 1987;46: 625-633

37. Bowles LK, Cooper JA, Howarth DJ, et al. Associations of haemostatic variables with body mass index: a communitybased study. Blood Coagul Fibrinolysis 2003;14:569-573

38. Cushman M, Lemaitre RN, Kuller LH, et al. Fibrinolytic activation markers predict myocardial infarction in the elderly. The Cardiovascular Health Study. Arterioscler Thromb Vasc Biol 1999;19:493-498

39. Decousus H. Chronobiology of hemostasis. In: Touitou Y, Haus E, eds. Biologic Rhythms in Clinical and Laboratory Medicine. Berlin, Germany: Springer; 1992:555-565

40. Toulon P, Vitoux JF, Leroy C, et al. Circulating activities during constant infusion of heparin or a low molecular weight derivative (enoxaparine): failure to demonstrate any circadian variations. Thromb Haemost 1987;58:1068-1072

41. Kluft C, Jie AFH, Rijken DC, Verheijen JH. Daytime fluctuations in blood of tissue-type plasminogen activator and its fast-acting inhibitor. Thromb Haemost 1988;59: 329-332

42. Bull GM, Brozonic M, Chakrabarti R, et al. Relationship of air temperature to various chemical, haematological and haemostatic variables. J Clin Pathol 1979;32:16-20 